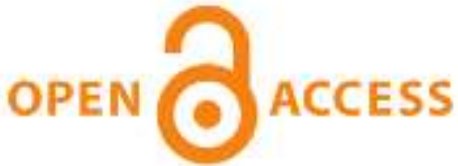

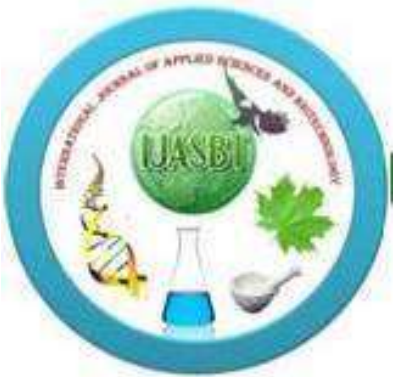 \\ International Journal of Applied Sciences and Biotechnology
}

\author{
A Rapid Publishing Journal
}

ISSN 2091-2609

\section{Indexing and Abstracting}

CrossRef, Google Scholar, Global Impact Factor, Genamics, Index Copernicus, Directory of Open Access Journals, WorldCat, Electronic Journals Library (EZB), Universitätsbibliothek Leipzig, Hamburg University, UTS (University of Technology, Sydney): Library, International Society of Universal Research in Sciences (EyeSource), Journal Seeker, WZB, Socolar, BioRes, Indian Science, Jadoun Science, JourInformatics, Journal Directory, JournalTOCs, Academic Journals Database, Journal Quality Evaluation Report, PDOAJ, Science Central, Journal Impact Factor, NewJour, Open Science Directory, Directory of Research Journals Indexing, Open Access Library, International Impact Factor Services, SciSeek, Cabell's Directories, Scientific Indexing Services, CiteFactor, UniSA Library, InfoBase Index, Infomine, Getinfo, Open Academic Journals Index, HINARI, etc.

\section{CODEN (Chemical Abstract Services, USA): IJASKD}
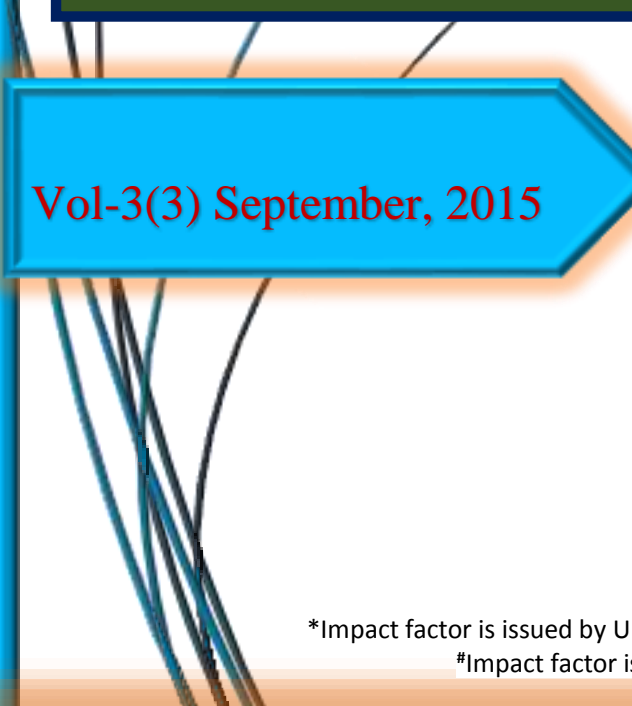

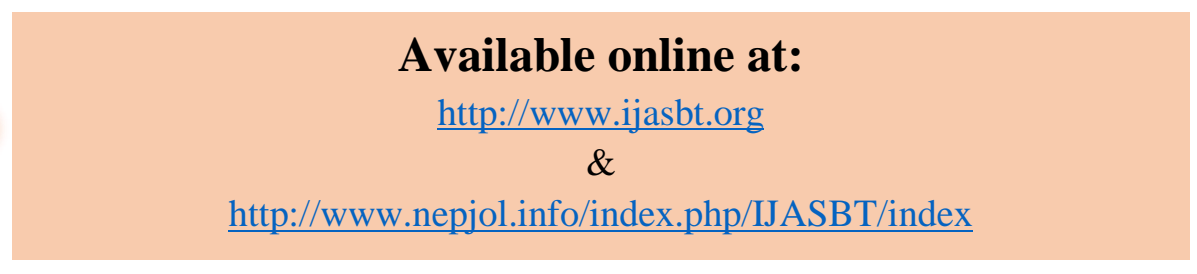

\section{Impact factor*: 1.422}

Scientific Journal Impact factor ${ }^{\#}: \mathbf{3 . 4 1 9}$

Index Copernicus Value: $\mathbf{6 . 0 2}$

IBI Factor 2015**: 4.19

*Impact factor is issued by Universal Impact Factor. Kindly note that this is not the IF of Journal Citation Report (JCR). \#Impact factor is issued by SJIF INNO SPACE; **Impact factor is issued by INFOBASE INDEX. 


\title{
CONSEQUENCES OF ENVIRONMENTALLY HAZARDOUS POLYCYCLIC AROMATIC HYDROCARBON- ANTHRACENE TREATMENT ON CYANOBACTERIA
}

\author{
Jignasha G. Patel, Nirmal Kumar, J. I.* and Shamiyan R. Khan \\ P.G. Department of Environmental Science and Technology, Institute of Science and Technology for Advanced Studies and Research (ISTAR), VallabhVidya \\ Nagar -388 120, Gujarat, India. \\ *Corresponding author email: nirmalkji@gmail.com; jignashapatel10@gmail.com
}

\begin{abstract}
The study was aimed to determine the chronic toxicity of Polynuclear aromatic hydrocarbon - Anthracene in response to pigments and metabolic study on three different cyanobacterial species such as Synechocystis sp., Anabaena fertilissima, and Nostoc muscorum. Test organisms were treated at different doses and encountered LC50/Mean Lethal Concentration (at which 50\% lethality/growth reduction occur) separately at $7.0 \mathrm{ppm}$ for Synechocystis sp, $5.0 \mathrm{ppm}$ for Anabaena fertilissima and $1.5 \mathrm{ppm}$ for Nostoc muscorum. The influence of anthracene on pigments, metabolites and enzymes was carried out. The test doses caused concentration dependent and decreased pigments like carotenoids and phycobilliproteins. Depletion of carbohydrate by 65 to $80 \%$ and proteins by 58 to $78 \%$ was encountered with rise in Anthracene concentrations after 16th day exposure in case of Synechocystis sp however, phenols were found to raise by 26 to $37 \%$ with increased anthracene concentrations. Similar trend also observed in other two tested blue green algae. Thus the Synechocystis sp.is more tolerant to anthracene treatments as compare to Anabaena fertillissima but Nostoc muscorum showed highest sensitivity to anthracene.
\end{abstract}

Key words: anthracene; photosynthetic pigments; metabolic contents; cyanobacteria.

\section{Introduction}

Polycyclic aromatic hydrocarbons (PAHs) are persistent organic compounds with two or more aromatic rings. They are formed by incomplete combustion of fossil fuels and pyrolysis of organic matter derived from human activities and as a result of natural events like forest fires. The Unites States Environmental Protection Agency (USEPA) is more concern to toxic, mutagenic and carcinogenic properties of PAHs, proposing some of them as priority pollutants including anthracene and phenenthrene (Simarro et al., 2011).

Anthracene is tricyclic aromatic hydrocarbons that are found in high concentrations in polycyclic aromatic hydrocarbon (PAH)-contaminated sediments, surface soils, and waste sites. Many past studies show that PAHs with lower molecular weight are toxic compounds, while high molecular weight compounds are significantly genotoxic (Juhaaz et al., 2000). These hydrophobic contaminants are widely distributed in the environment, occurring as natural constituents of fossil fuels and their anthropogenic pyrolysis products (Cerniglia 1992; Kanaly and Harayama, 2000). Despite they have been shown to be toxic to fish and algae (Sutherland et al., 1992). A variety of bacterial species have been isolated that have the ability to utilize anthracene or phenanthrene as the sole source of carbon and energy (Sutherland et al., 1995). The fates of these compounds in the environment and the remediation of PAH-contaminated sites are, therefore, of high scientific and public interest. Cyanobacteria, a group of prokaryotic, oxygen evolving, photosynthetic Gram-negative bacteria, survive in a wide variety of extreme environmental conditions (Herrero et al., 2001). They are widespread in many ecosystems, including polluted ones (Sorkhoh et al., 1992). Marine cyanobacteria can oxidize aromatic hydrocarbons under photoautotrophic growth conditions. Evidence supporting the effect of anthracene on cyanobacterial metabolites is still very limited. Some bacterial genera including Pseudomonas, Alcaligenes, Vibrio, Mycobacterium, Rhodococcus, Cyclocla sticus are degrade PAHs used as carbon source to derive energy (Berardesco et al.,1998).

Metabolic response and toxicity of each and every chemical differs from one to another organism therefore, it is essential to know about same by using the anthracene on three selected cyanobacteria. However, to our knowledge, no previous report on toxicity of anthracene on the proposed work so as to establish the consequences and deleterious effects on growth, photosynthetic pigmentation, metabolites and enzymatic response of three species of cyanobacteria viz., Anabaena fertillissima, Nostoc 
muscorum, and Synechocystis sp. by anthracene. Moreover, Nirmal kumar et al (2014) and Patel et al., (2013) explored chronic toxicity of pyrene in response to pigments, metabolic and enzymatic variation on certain sp. of cyanobacteria.

\section{Materials and Methods}

\section{Organism and Culture Conditions}

For the present study, axenic cultures of two filamentous, nitrogen-fixing, heterocystous cyanobacterium Anabaena fertilissima, Nostoc muscorum and one unicellular nonheterocyst forming cyanobacterium Synechocystis sp. procured from the Centre for Conservation and Utilization of Blue Green Algae, IARI, New Delhi, India. They were grown at $25 \pm 2^{\circ} \mathrm{C}$ in BG-11 medium (Rippka et al., 1979) under an illumination of 3,000 lux light with a photoperiod of 14:10 (Light/Dark). Exponentially grown cyanobacterial cells were used throughout the experiment. Each experiment was conducted in replicates of three and their $\pm \mathrm{SE}$ values were calculated.

\section{Anthracene Treatment}

Anthracene (98\% purity) was two aromatic ring structure pale yellow in colour and crystalline chemical, procured from Sigma Aldrich chemistry, USA. Exponentially growing $2 \mathrm{ml}$ of the culture was inoculated to each effective dose and made up to $20.0 \mathrm{ml}$. For each experiment, the solution of anthracene was freshly prepared from 1 to 20 ppm doses. Growth retardation in terms of chlorophyll - a for LC 50 doses were selected in the culture treated with 5.0 ppm (Anabaena fertilissima), 7.0 ppm (Synechocystis sp.) and $1.5 \mathrm{ppm}$ (Nostoc muscorum). Thus, three concentrations for each species were selected for the present investigation to carry out the response to selected cyanobacteria i.e one is $\mathrm{LC}_{50}$ concentration, another is lower and the third is higher to $\mathrm{LC}_{50}$ concentration. (table.1).Growth, pigments and biochemical response of three selected cyanobacteria to anthracene was studied at an interval of four days up to sixteen days. At the end of every four days, the treated as well as untreated cultures were assayed for various pigments, metabolites and enzymes. Analytical grade chemicals (Merck Ltd, and Himedia Ltd, India) were used throughout the study.

\section{Growth and Photosynthetic Pigment Measurement}

Growth was measured by determining the chlorophyll- $a$ content (Jeffrey \& Humphrey 1975). Cells were harvested by centrifugation, suspended in $80 \%$ acetone, and left in dark at $4^{\circ} \mathrm{C}$ overnight for extraction. The suspension was again centrifuged and the optical density of the supernatant was read at 630 and $663 \mathrm{~nm}$.

Carotenoid was extracted in $80 \%$ acetone for $24 \mathrm{~h}$ at $4{ }^{\circ} \mathrm{C}$ and determined according to Parsons and Strickland (1963). The phycobiliproteins pigments were estimated according to Bennett and Bogorad (1973). After extraction of chlorophyll- $a$ using acetone, cells were suspended in 50
$\mathrm{mM}$ phosphate buffer ( $\mathrm{pH}$ 6.7). Cyanobacterial cells were lysed by repeatedly freezing and thawing, and the crude extract was centrifuged at $12,000 \mathrm{~g}$ for $15 \mathrm{~min}$ at $4{ }^{\circ} \mathrm{C}$. The optical density of the supernatant was read at 562, 615, and $652 \mathrm{~nm}$ with phosphate buffer as the blank.

\section{Estimation of Metabolites}

Total carbohydrate release was determined spectrophotometrically by the anthrone method using glucose as the standard (Hedge \& Hofreitte 1991). The protein content of the crude cell-free extract was estimated according to Lowry and colleagues (1951) using bovine serum albumin as the standard. An improved colorimetric determination of amino acids with the use of ninhydrin was performed (Lee \& Takahanshi 1966). Phenol estimation was carried out with Folin-Ciocalteu reagent (Malick \& Singh 1980).

\section{Results and Discussion}

\section{LC $C_{50}$ determination}

LC $_{50}$ of Synechocystis sp., A. fertilissima and, N. muscorum for anthracene was found to be 7.0, 5.0 and $1.5 \mathrm{ppm}$ respectively. Based upon the $\mathrm{LC}_{50}$ doses, three different concentrations for each organism were selected for the study as represented in Table. 1

Table 1: Anthracene treatments based upon determination of $\mathrm{LC}_{50}$ on different Cyanobacterial species.

\begin{tabular}{|l|l|l|l|}
\hline Organisms & $\begin{array}{l}\text { Synechocystis } \\
\text { sp. }\end{array}$ & $\begin{array}{l}\text { Anabaena } \\
\text { fertilissima }\end{array}$ & $\begin{array}{l}\text { Nostoc } \\
\text { muscorum }\end{array}$ \\
\hline $\begin{array}{l}\text { Lower to } \\
\text { LC }\end{array}$ & 3.5 & 2.5 & 0.75 \\
\hline LC $_{50}(\mathrm{ppm})$ & 7.0 & 5.0 & 1.5 \\
\hline $\begin{array}{l}\text { Higher to } \\
\text { LC }\end{array}$ & 14.0 & 10.0 & $3.0 \mathrm{ppm})$ \\
\hline
\end{tabular}

\section{Growth in Terms of Chlorophyll-a}

After 4-days exposure of high anthracene treatment, chlorophyll-a content showed a significant decrease by $75 \%$ at $3.0 \mathrm{ppm}$ in N. muscorum, by $78 \%$ at $5.0 \mathrm{ppm}$ in $A$. fertilissima and $67 \%$ Synechocystis sp. at $7.0 \mathrm{ppm}$ in relative to control. The maximum reduction in chlorophyll-a content was recorded in N.muscorum (91\% at $3.0 \mathrm{ppm})$, and the lowest in Synechocystis sp. (86\% at $14.0 \mathrm{ppm}$ ) followed by A. fertilissima (90\% at $10.0 \mathrm{ppm}$ ) by the end of $16^{\text {th }}$ day of treatment (Fig. 1a). In present study, chlorophyll synthesis was found to be severely affected by the graded concentrations of anthracene and diminish in the growth of cultures between 6.0 to $14.0 \mathrm{ppm}$ doses. Moreover, growth rate was decline more than $50 \%$ in the maximum concentrations of anthracene which is substantiated the findings of Sikkema et al, (1995) who stated that "the inhibition of chlorophyll synthesis by pesticides in Anabaena sp. believed to be the disruption of biological membrane". The lipophilic character of aromatic hydrocarbon can alter the membrane fluidity, permeability of the membrane, cause lipid bilayer disruption and diminish the energy transduction and affect activity of 
membrane associate proteins (Heipieper et al., 1995). Anthracene showed the most deleterious effect on the growth of Nostoc muscorum among the three tested cyanobacterial species.

\section{Pigment composition}

Pigment response of all the three organisms to various concentrations of the low molecular weight anthracene has been represented in Fig 1 (b-e) Low concentration (3.5 ppm) of anthracene treated to Synechocystis sp. retarded carotenoid, phycocyanin, allophycocyanin and phycoerythrin contents by $11,7,11$ and $13 \%$, respectively whereas $14.0 \mathrm{ppm}$ of anthracene does sharply lowered carotenoid and phycocyanin, allophycocyanin and phycoerythrin contents by $90,93,81$ and $68 \%$, respectively . Similar observations were made while studying on the growth, photosynthesis, active oxygen species and antioxidants responses of paddy field cyanobacterium Plectonema boryanum to pesticide endosulfan stress (Prasad et al., 2005).
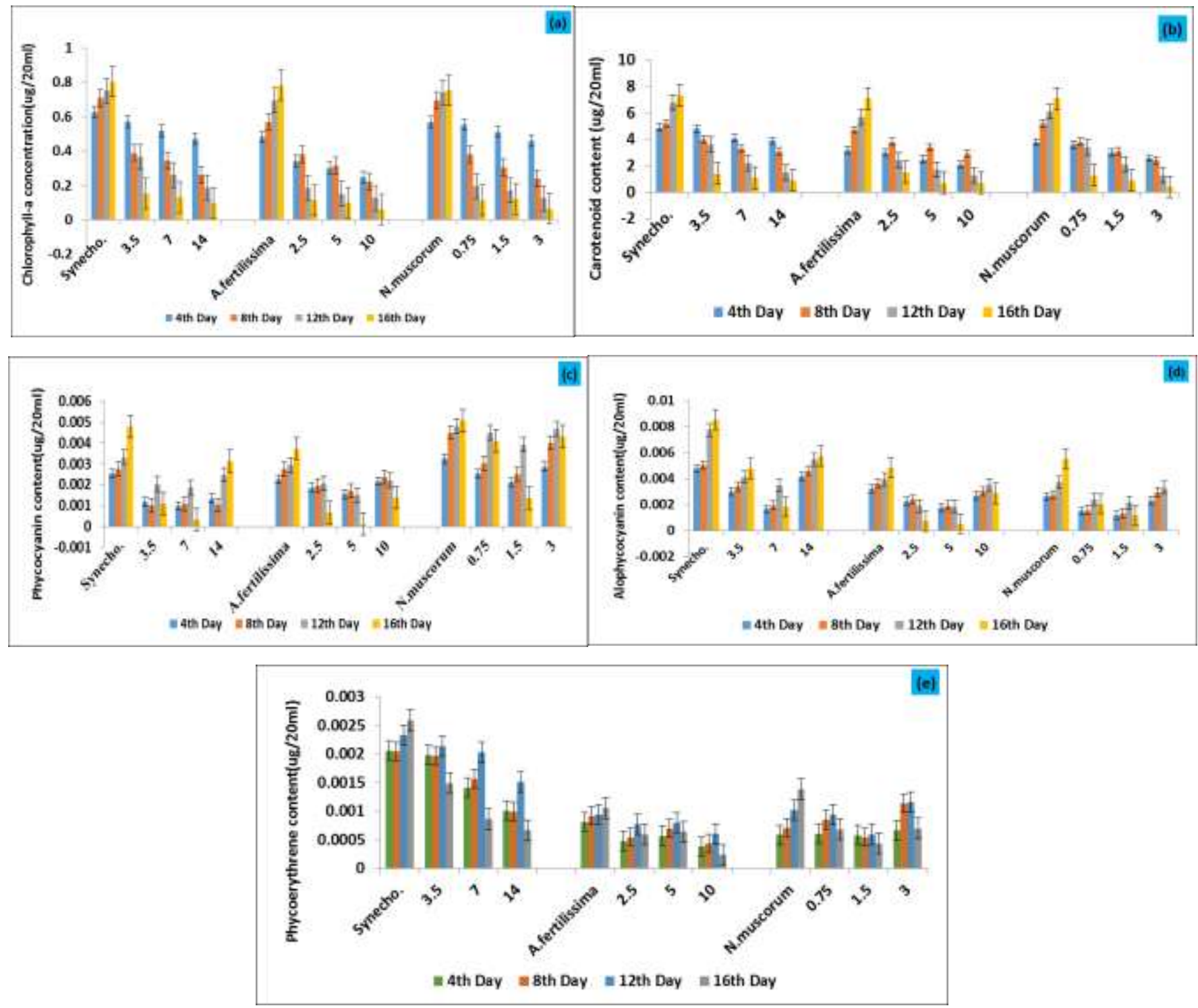

Fig. 1: (a) Chlorophyll-a content ( $\mu \mathrm{g} / 20 \mathrm{ml})$ in Synechocystis sp., Anabaena fertilissima and Nostoc muscorum at different doses of anthracene (in ppm); (b) Carotenoid content $(\mu \mathrm{g} / 20 \mathrm{ml})$ in Synechocystis sp., Anabaena fertilissima.and Nostoc muscorum at different doses of anthracene (in ppm); (c) Phycocyanin content ( $\mu \mathrm{g} / 20 \mathrm{ml})$ in Synechocystis sp., Anabaena fertilissima.and Nostoc muscorum at different doses of anthracene; (d) Allophycocyanin content ( $\mu \mathrm{g}$ $120 \mathrm{ml}$ ) in Synechocystis sp., Anabaena fertilissima.and Nostoc muscorum at different doses of anthracene; (e) Phycoerythrene content ( $\mu \mathrm{g} / 20 \mathrm{ml})$ in Synechocystis sp., Anabaena fertilissima.and Nostoc muscorum at different doses of anthracene 
Photosynthetic and accessory pigment contents of $A$. fertilissima and $N$. muscorum decreased continuously with increasing anthracene concentrations and exposure (days). The reduction was significant at the highest anthracene concentration i.e. $10.0 \mathrm{ppm}$ and $6.0 \mathrm{ppm}$ to A. fertilissima and $N$. muscorum respectively. The pigments such as carotenoids, phycocyanin, allophycocyanin and phycoerythrin reduced by $93,97,89$ and $87 \%$ respectively by 16 days in N.muscorum cultures. Similarly, the percentage reduction of carotenoids, phycocyanin, allophycocyanin and phycoerythrin were registered by 95 , 92,82 and $81 \%$ respectively in A. fertilissima. These watersoluble pigments were found to decline at a faster rate than those of chlrophyll-a and carotenoids. Mohapatra and Schiewer (2000) have demonstrated with organophosphorous insecticides that the toxicantmembrane interaction and dispersion of lipoprotein membrane are responsible for change in behavior and pigment content of Synechocystis PCC 6803 which also corroborated with the findings of Mostafa and Helling (2002) who suggested that "drop in chlorophyll-a, carotenoid and phycobiliprotein contents might be ascribed due to the inhibition of pigment synthesis directly by the insecticide or accelerated degradation of pigments due to increased Active Oxygen Species (AOS)and PAH thylakoid membrane degradation".

\section{Biochemical Metabolites}

The retardation of carbohydrate content might be due to the interference of chemicals with the photosynthesis process (Padhy et al., 1985). Significant reduction in carbohydrates of Synechocystis sp., A.fertilissima and N.muscorum was observed with increasing concentrations of anthracene (Fig. 2a). Significant reduction in carbohydrates upon raising the concentration of anthracene was observed by 80,89 and $92 \%$ in Synechocystis sp., A.fertilissima and N.muscorum respectively after 16 days, depicting a concentrationdependent inhibition. Anthracene at 3.5, 7.0 and $14.0 \mathrm{ppm}$ diminished the protein content of cyanobacterium Synechocystis sp. by 58, 70 and $78 \%$, respectively on 16 days of treatment, which were confirmed with the findings of Shehata et al., (2001). Although, initial protein levels raised during 4th and 8th day in the other two test species A. fertilissima and N.muscorum, respectively in response to lower concentrations of anthracene. However the protein levels were fallen consistently by $70 \%$ and $84 \%$ at $10.0 \mathrm{ppm}$ and $3.0 \mathrm{ppm}$ after 16 days. However it has been noticed that anthracene suppressed the total protein content of all three organisms in comparison to control (Fig. 2b).
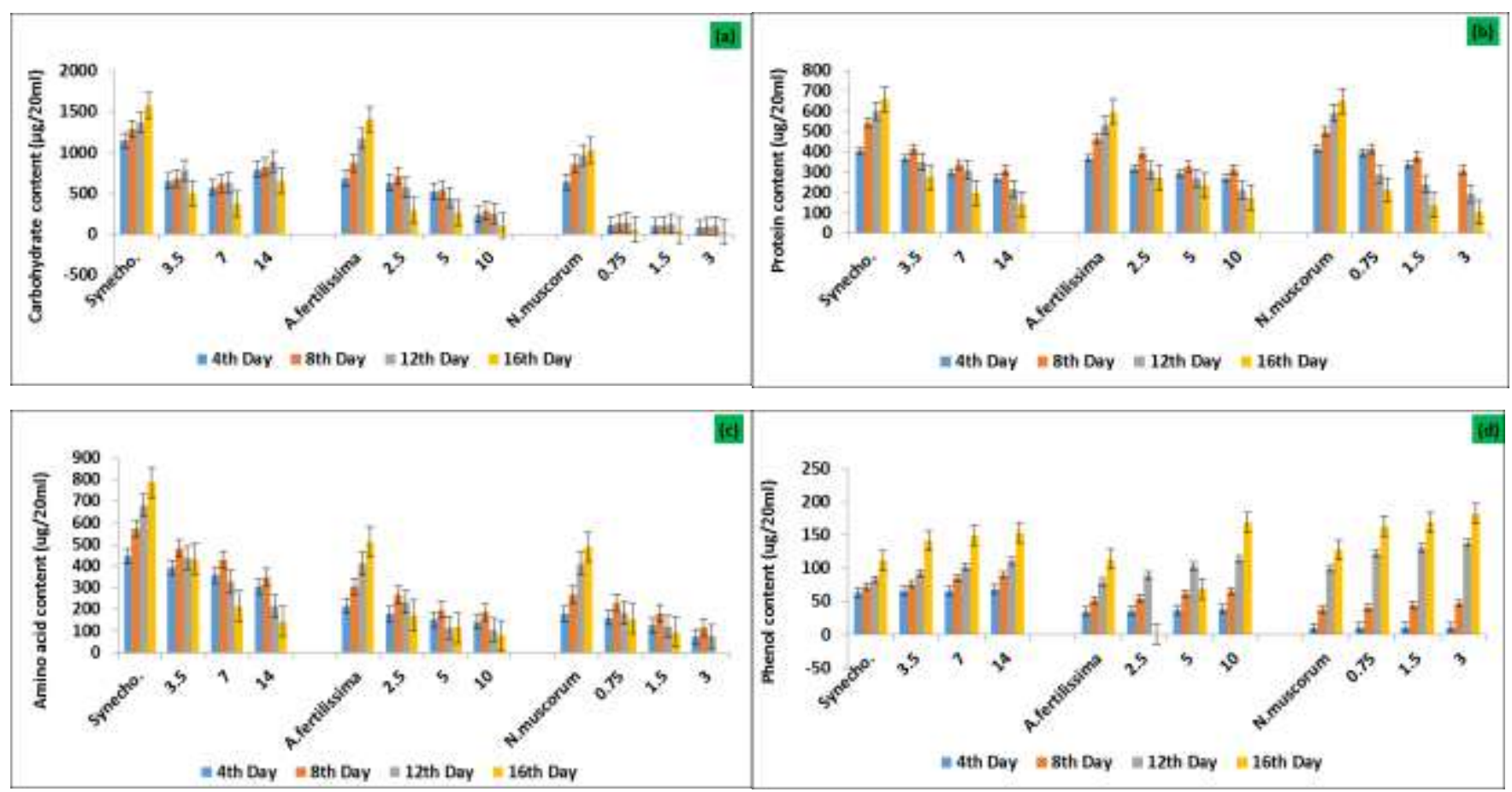

Fig. 2: (a) Carbohydrate content $(\mu \mathrm{g} / 20 \mathrm{ml})$ in Synechocystis sp., Anabaena fertilissima.and Nostoc muscorum at different doses of anthracene; (b) Protein content $(\mu \mathrm{g} / 20 \mathrm{ml})$ in Synechocystis sp., Anabaena fertilissima.and Nostoc muscorum at different doses of anthracene; (c) Aminoacid content ( $\mu \mathrm{g} / 20 \mathrm{ml})$ in Synechocystis sp., Anabaena fertilissima and Nostoc muscorum at different doses of anthracene; (d) Phenol content ( $\mu \mathrm{g} / 20 \mathrm{ml})$ in Synechocystis sp., Anabaena fertilissima.and Nostoc muscorum at different doses of anthracene (ppm). 
Reduction in Amino acids of Synechocystis sp., A.fertilissima and N.muscorum with respect to highest concentrations of anthracene were recorded by 81,89 and $93 \%$ respectively after 16 days. After a consistent fall in the amino acids content of the tested organisms was registered in response to the treated concentrations of anthracene (Fig. 2c). Changes in amino acid concentration may be due to synthesis from endogenous precursors or inhibition of normal catabolism (Measures et al., 1975). Phenols are aromatic molecules, widespread in photosynthetic organisms, which are produced during the stress conditions. Phenol content enhanced in respective to treated cells of Synechocystis sp., as compared to the control until 8th day (Fig. 2d). However, from 12th day onwards, phenol levels shooted up with respect to higher concentrations of the anthracene as well as exposure periods. Moreover, phenol content of Synechocystis sp. was registered to increase by $37 \%$ when treated with 14 ppm after 16 days. Besides, phenolic concentration in the other two species, A.fertilissima and N.muscorum raised by 42 and $48 \%$ respectively at 10.0 and $3.0 \mathrm{ppm}$ concentrations of the anthracene Pradnya et al., (2004); Calow et al., (1990) suggested that "all types of toxic stress induce metabolic change in the organism, leading to depletion of its energy reserve that results in an adverse effect on its growth and biochemical composition.

\section{Conclusion}

Experiments were conducted with a view to determining the detrimental and harmful effects of anthracene on the concentration dependent decreased in growth, photosynthetic pigments and metabolic activities of tested cyanobacteria. Indeed anthracene, an indicator of PAHs element harmful to the useful cyanobacteria. The results suggest that Nostoc muscorum was the most susceptible organism while the order of tolerance to each organism towards PAH can be described as Synechocystis sp. being more tolerant than A. fertilissima.

\section{References}

Bennett A, and Bogorad L (1973) Complementary Chromatic Adaptation in a Filamentous Blue-Green Alga. J. of Cell Biology 58: 419-435. DOI: 10.1083/jcb.58.2.419

Berardesco G, Dyhrman S, Gallagher E, and Shiaris MP (1998) Spatial and Temporal Variation of Phenanthrene Degrading Bacteria in Intertidal Sediments. Appl. Environ. Microbiol. 64(7): 2560-2565.

Calow P, and Sibly RM (1990) A Physiological basis of Population Processes: Ecotoxicological Implications. Funct. Eco. 4: 283-288. DOI: $10.2307 / 2389587$

Cerniglia CE (1992) Biodegradation of polycyclic aromatic hydrocarbons. Biodeg. 3: 351-368. DOI: 10.1007/BF00129093

Hedge JE and Hofreitte BT (1991) Carbohydrates Chemistry. In Sadasivam S and Manickam A (Eds). Biochemical
Methods for Agriculture Science, Wiley Estern Ltd. Publication $\mathbf{8}$.

Heipieper HJ, Loffeled B, Keweloh H and De Bont JE (1995) The cis/tran Isomerisation of Unsaturated fatty acids in Psudomonas putida S12: An Indicator for Environmental Stress due to Organic Compounds. Chemosphere 30: 1041-1051. DOI: 10.1016/0045-6535(95)00015-Z

Herrero A, Muro-Pastor A and Flores ME (2001) Nitrogen Controlling Cyanobacteria. J. Bact. 183: 411-425. DOI: 10.1128/JB.183.2.411-425.2001

Jeffrey SW, and Humphrey GF (1975) New Spectrophotometric Equations for Determining Chlorophylls- a, b, c1 and c2 in Higher Plants, Algae and Natural Populations. Biochem. Phys. Pflanzen 167: 191-194.

Juhasz AL and Naidu R (2000) Bioremediation of High Molecular Weight Polycyclic Aromatic Hydrocarbons: A review of the Microbial Degradation of Benzo (a) pyrene. Int. J. Biodet. Biodeg. 45: 57-88. DOI: 10.1016/S09648305(00)00052-4

Kanaly RA and Harayama S (2000) Biodegradation of HighMolecular Weight Polycyclic Aromatic Hydrocarbons by Bacteria. J. Bact. 182: 2059-2067.DOI: 10.1128/JB.182.8.2059-2067.2000

Kumar JIN, Patel JG, Kumar RN and Khan SR (2014) Chronic response of three different Cyanobacterial species on growth pigment and metabolic variations to the high molecular weight Polycyclic Aromatic HydrocarbonPyrene Poly. Aro. Com. 34 (2): 143-160. DOI: 10.1080/10406638.2013.867514

Kun E and Abood LG (1949) Colorimetric estimation of Succinic Dehydrogenase by Triphenyl Tetrazolium Chloride. Sci. 109: 144-146. DOI: $10.1126 /$ science.109.2824.144

Lee Y and Takahasi T (1966) An Imported Colorimetric Determination of Amino acids with the use of Ninhydrin. Ann. Bioch. 14: 71-77. DOI: 10.1016/00032697(66)90057-1

Lowry OH, Rosenbrough NH, Farr AL and Randall RJ (1951) Protein measurements with Folin Phenol Reagent. J. Bio. Chem. 193: 265-275.

Malick CP and Singh MB (1980) Plant enzymology and histo enzymology, kalyani publishers, New Delhi 286.

Measures JC (1975) Role of Amino acids in Osmoregulation of Non Halophilic Bacteria. Nature (London) 257: 398400. DOI: $10.1038 / 257398 \mathrm{a} 0$

Mohapatra PK and Schiewer U (2000) Dimethoate and quinalphos toxicity: Pattern of photosynthetic pigment degradation and recovery in Synechocystis sp. PCC 6803. Archi. Hydro. 134: 79-94. DOI: 10.1038/257398a0

Mostafa FI and Helling CS (2002) Impact of four Pesticides on the Growth and Metabolic Activities of Two Photosynthetic Algae. J Env. Sci. Health 37: 417- 444. DOI: 10.1081/PFC-120014873

Padhy RN (1985) Cyanobacteria and Pesticides. Residue Review 95: 1- 44. DOI: 10.1371/journal.pone.0053445 
Pamiljans V, Krishnaswamy PR, Dumville G and Meister A (1962) Studies on the mechanism of Glutamine Synthetase: Isolation and Properties of the Enzyme from Sheep brain. Biochem. 1: 153-158. DOI: 10.1021/bi00907a023

Parsons TR and Strickland JD (1963) Discussion of Spectrophotometric determination of Marine Plant Pigments with Revised equations for Ascertaining Chlorophylls and Carotenoids. J. Mari. Res. 21:155-163.

Patel JG, Kumar JIN, Kumar RN and Khan SR (2013) Chronic toxicity of high molecular weight polynuclear aromatic hydrocarbon- pyrene on freshwater cyanobacterium Anabaena fertlissima Rao. Int. J Env. 2(1): 175-183. DOI: $10.3126 /$ ije.v2i1.9220

Pradnya PK, Bharati JB, Neelima MD and Seema SS (2004) Biodegradation of Organophosphorous Pesticides. Procceeding of Ind. Nat. Sci. Acad. 70(1): 57-70.

Prasad SM, Kumar D and Zeeshan M (2005) Growth, Photosynthesis, Active oxygen species and Antioxidants Responses of Paddy field Cyanobacterium Plectonema boryanum to Endosulfan stress. J. General Appl. Micro. 51: 115-123. DOI: 10.2323 /jgam.51.115

Rippka R, Deruelles S, Waterbury JB, Herdman M and Stanier RM (1979) Generic assignments, Strain Histories and Properties of Pure Cultures of Cyanobacteria. J. Gen. Micro. 111: 1-61. DOI: 10.1099/00221287-111-1-1

Sempruch C, Ciepiela AP, Sprawka I and Chrzanowski G (2008) Purification and some physicochemical properties of
Nitrate reductase isolated from winter triticale seedlings. Electro. J. Poli. Agri. 11:1.

Shehata AI, Arif IAW and Aqeel FA (2001) Isolation and Characterization of DNA and Protein from Endosulfan Resistant Mutant (endo) of the Cyanobacterium Anabaena flosaquae. Saudi J. Bio. Sci. 8(1): 61-69.

Sikkema JJ, De Bont A and Poolman B (1995) Mechanisms of Membrane Toxicity of Hydrocarbons. Micro. Mole. Bio. Rev. 59: 201-222.

Simarro R, Gonzalez N, Bautista LF, Sanz R and Molina MC (2011) Optimisation of key Abiotic factors of PAH (naphthalene, phenanthrene and anthracene) Biodegradation process by a bacterial Consortium. Water, Air Soil Pol. 217: 365-374. DOI: 10.1007/s11270-0100593-8

Sorkhoh N, Al-Hasan R, Radwan SS and Hopner T (1992) Selfcleaning of the Gulf. Nature (London) 359: 109. DOI: $10.1038 / 359109 \mathrm{a} 0$

Sutherland JB, Rafii F, Khan AA and Cerniglia CE (1995) Mechanisms of Polycyclic Aromatic Hydrocarbon Degradation, In: Young LY and Cerniglia CE (Ed) Microbilogical Transformation and degradation of toxic organic Chemistry, Wiley-Liss, New York: 169-306.

Sutherland JB, Selby AL, Freeman JP, Fu PP, Miller DW and Cerniglia CE (1992) Identification of xyloside conjugates formed from Anthracene by Rhizoctonia solani. Myco. Res. 96: 509-517. DOI: 10.1016/S0953-7562(09)81100-3 